\title{
Are we ready for a National Forest Information System? State of the art of forest maps and airborne laser scanning data availability in Italy
}

\author{
Giovanni D'Amico(1), \\ Elia Vangi ${ }^{(1-2)}$, \\ Saverio Francini ${ }^{(1-2-3)}$ \\ Francesca Giannetti ${ }^{(1-4-5)}$, \\ Antonino Nicolaci ${ }^{(6)}$, \\ Davide Travaglini ${ }^{(1)}$, \\ Lorenzo Massai ${ }^{(4-5)}$, \\ Yamuna Giambastiani ${ }^{(4-5-7)}$, \\ Carlo Terranova ${ }^{(8)}$, \\ Gherardo Chirici ${ }^{(1-5)}$
}

\begin{abstract}
Forest planning, forest management, and forest policy require updated, reliable, and harmonized spatial datasets. In Italy a national geographic Forest Information System (FIS) designed to store and facilitate the access and analysis of spatial datasets is still missing. Among the different information layers which are useful to start populating a FIS, two are essential for their multiple use in the assessment of forest resources: (i) forest mapping, and (ii) data from Airborne Laser Scanning (ALS). Both layers are not available wall-to-wall for Italy, though different local sources of information potentially useful for their implementation already exist. The objectives of this work were to: (i) review forest maps and ALS data availability in Italy; (ii) develop for the first time a high resolution forest mask of Italy which was validated against the official statistics of the Italian National Forest Inventory; (iii) develop the first mosaic of all the main ALS data available in Italy producing a consistent Canopy Height Model (CHM). An on-line geographic FIS with free access to both layers from (ii) and (iii) was developed for demonstration purposes. The total area of forest and other wooded lands computed from the forest mask was 102,608.82 $\mathrm{km}^{2}$ (34\% of the Italian territory), i.e., $1.9 \%$ less than the NFI benchmark estimate. This map is currently the best wall-to-wall forest mask available for Italy. We showed that only the $63 \%$ of the Italian territory (the $60 \%$ of the forest area) is covered by ALS data. These results highlight the urgent need for a national strategy to complete the availability of forest data in Italy.
\end{abstract}

Keywords: National Datasets, Forest Inventory, Forest Monitoring, Forest Mask, Airborne Laser Scanning, LiDAR

\section{Introduction}

Forest mapping is an important source of information for assessing woodland resources and a key issue for any National Forest Inventory (NFI) programme (Waser et al. 2017). Nowadays, global and nationwide wall-to-wall, raster-type maps of forest resources, based on satellite images, laser scanning, aerial orthomosaic and pho-

togrammetric point cloud data are considered essential to monitor and quantify forest variables (Hansen et al. 2013, Waser et al. 2017, Kangas et al. 2018, Chirici et al. 2020). Forest maps are currently produced on the basis of remote sensing technologies at different spatial scales for global or continental forest resources. Here, a brief review of the most important and recent

(1) Dept. of Agriculture, Food, Environment and Forestry (DAGRI), University of Florence, v. San Bonaventura, 13, 50145 Florence (Italy); (2) Dept. of Bioscience and Territory (DiBT), University of Molise, c.da Fonte Lappone, I-86090 Pesche, IS (Italy); (3) Dept. of Innovation in Biological, Agro-Food and Forest System (DIBAF), University of Tuscia, v. San Camillo de Lellis, I-01100 Viterbo (Italy); (4) Bluebiloba startup Innovativa s.r.l., v. C. Salutati 78, 50126 Florence (Italy); (5) ForTech, University of Florence joint laboratory, v. San Bonaventura 13, 50145 Florence (Italy); (6) Dept. of Computer Engineering, Modeling, Electronics, and Systems Science (DIMES), University of Calabria, v. P. Bucci 41C, I-87036 Rende, CS (Italy); (7) LAMMA Consortium - Environmental Modelling and Monitoring Laboratory for Sustainable Development, Florence (Italy); (8) Geoportale Nazionale, Italian Ministry of the Environment, v. Cristoforo Colombo 44, 00147 Rome (Italy)

@ Giovanni D’Amico (giovanni.damico@unifi.it)

Received: Sep 07, 2020 - Accepted: Feb 18, 2021

Citation: D’Amico G, Vangi E, Francini S, Giannetti F, Nicolaci A, Travaglini D, Massai L, Giambastiani Y, Terranova C, Chirici G (2021). Are we ready for a National Forest Information System? State of the art of forest maps and airborne laser scanning data availability in Italy. iForest 14: 144-154. - doi: 10.3832/ifor3648-014 [online 2021-03-23]

efforts in forest mapping at the European and global level is reported.

Copernicus, the European programme for Earth observation (https://www.copernicu s.eu), developed several layers potentially useful for forest monitoring, in particular the European Forest High Resolution Layers (HRL), and more specifically: (i) the tree cover density (TCD) expressed in percent of tree cover; (ii) the dominant leaf type (DLT) based on the dominance of broadleaved or coniferous species; and (iii) the forest type products (FTY), a forest mask which closely mimics the FAO forest definition. These layers were developed primarily with Sentinel-2 time series for the year 2018, and complemented for the years 2012 and 2015 by Landsat 8 , SPOT-5 and ResourceSat-2 satellite data (Langanke 2017), and are currently available with resolutions ranging between 10 and $100 \mathrm{~m}$. Also the Copernicus Global Land Service has recently released the 2015 global land cover map at $100 \mathrm{~m}$ resolution (Buchhorn et al. 2019), updating the harmonized global land cover classification for the year 2000 based on SPOT4 images, originally produced by the Global Vegetation Monitoring unit of the Join Research Centre of the European Commission.

The Japan Aerospace Exploration Agency (JAXA) produced a global forest/non forest map for the reference years 2007 and 2009 
based on the classification of ALOS and ALOS-2 satellite radar images, with a resolution of $10 \mathrm{~m}$ and a declared accuracy of $84 \%$ compared to the ground base data set (JAXA 2016).

The World Resources Institute, within the framework of Global Forest Watch, developed an online forest monitoring data set based on the analysis of Landsat multitemporal series, producing the global map of tree cover density for the reference year 2010 and a forest gain/loss map for the period 2001-2019 (Hansen et al. 2013).

The above maps are considered useful to monitor forest resources at global or continental scales (Hansen et al. 2013), however they can be affected by large errors at national or regional level (Giannetti et al. 2020). For this reason none of the existing forest maps implemented at continental or global level are considered reliable for operational purposes at national level. As a consequence, forest maps have been developed independently by several countries, such as Sweden (Nilsson et al. 2017), Norway (Naesset 2007), Finland (Maltamo et al. 2014), Switzerland (Waser et al. 2017), Spain (Alberdi et al. 2017), United Kingdom (Smith et al. 2010), USA (McRoberts et al. 2005), France (Garnier et al. 2019). These maps are considered essential to infer forest statistics in NFIs (Di Biase et al. 2018), to assess forest variables at national scale and support forest owners in planning silvicultural interventions at local scale (Kangas et al. 2018), to quantify forest ecosystems services (Vizzarri et al. 2017) or support precision forestry (Corona et al. 2017). Usually, forest resource maps developed in the context of NFIs have been produced at a scale congruent with the size of the sampling units used to acquire the information in the field, in order to reduce the costs of management activities for forest owners (Kangas et al. 2018).

In order to support forest management or planning, the spatial data produced by modern NFIs are routinely implemented in geographic Forest Information Systems (FIS) which allow forest managers, forest owners and government authorities to query forest data through on-line webbased systems. Examples are available for Norway (https://kilden.nibio.no/), Sweden (https://kartor.skogsstyrelsen.se/kartor/?st artapp=skogligagrunddata), Finland (https: //kartta.paikkatietoikkuna.fi/), Spain (http:// lidarrioja.agrestaweb.org/\#!/map) or France (https://www.geoportail.gouv.fr/carte). According to White et al. (2016), the Italian NFI program cannot be considered an Enhanced Forest Inventory, as it does not provide wall-to-wall maps but only estimates of forest variables aggregated over large geographic regions. As a result, a forest mapping process over Italy is still missing within the $\mathrm{NFI}$ program, although multiple mapping projects have been carried out at local scale. Nonetheless, in 2018 the Italian Parliament enacted a new Forest law clearly recognizing the need of a na- tional high resolution forest map as a key tool to set up a country-level forest strategy. This calls for the recognition of existing forest maps and an evaluation of their consistency in terms of forest definitions and nomenclature systems.

Wall-to-wall maps from remotely sensed (RS) data can be used for the estimation of forest variables, also over small areas (Chirici et al. 2020), e.g., growing stock volume (Saarela et al. 2016), biomass (Naesset et al. 2011), forest structural variables and diversity indices (Mura et al. 2016). Among the different types of available RS technologies, Airborne Laser Scanner (ALS) emerged as the most effective to derive such maps and to support the development and parameterization of models for a broad range of information needed to enhance NFIs (Maltamo et al. 2014, White et al. 2016). Indeed, ALS data allow to capture highly-detailed structural properties of forests (Hyyppä et al. 2008, Holopainen et al. 2014). The advantages of ALS in mapping forest variables are well documented in the context of NFIs (Naesset 2007, McRoberts et al. 2013), local forest inventories (Mura et al. 2016, Bottalico et al. 2017), biodiversity monitoring (Wulder et al. 2008, Valbuena et al. 2013), and characterization of wildlife habitats (Vogeler et al. 2014). In operational wall-to-wall forest inventories, a two-stage procedure using ALS data and field plots by the so-called Area-Based Approach (ABA - Naesset 2002) is commonly applied, and several countries (e.g., Norway, Sweden, and Finland) already used this technology for implementing their NFIs (Maltamo et al. 2007, Naesset 2007, Nilsson et al. 2017).

In Italy the first studies aimed to estimate forest variables based on ALS data date back to early 2000 (Barilotti et al. 2005). An excursus on the first decade of ALS applications in Italy is reported in Montaghi et al. (2013). More recently, Mura et al. (2016) developed a methodological approach to map a multiple variation index of forest structural diversity with a statistically rigorous inference approach. Chirici et al. (2016) compared four model-assisted estimates of total forest aboveground biomass obtained using ALS echo-based and CHM metrics. Chirici et al. (2018) quantified forest windthrow damages in Tuscany after the storm of March 2015 using post-event ALS data, while Giannetti et al. (2018) assessed single-tree attributes in a complex mixed Mediterranean forests by combining ALS and terrestrial laser scanner (TLS) data.

Despite a fairly rapid growth of these techniques, wall-to-wall ALS data are currently unavailable for Italy (Montaghi et al. 2013, Scrinzi et al. 2017), though several local data sets have been acquired recently. Further, an overview of all the ALS data sets available in Italy is still missing, albeit this information is crucial to integrate ALS data with other source of information, such as that from field surveys conducted by the Italian NFI, or to plan future ALS ac- quisitions (Corona et al. 2017).

The general objective of this work is to assess the consistency of forest maps and ALS data currently available in Italy, as a preliminary activity to a future implementation of a National Forest Information System. More specifically this paper is aimed to: (i) investigate if existing local forest maps can be combined to achieve a national high resolution forest/non-forest map (forest mask), as well as to compare the forest area estimates derived from this map with those obtained from the Italian $\mathrm{NFI}$; for comparative purposes we assessed the quality of other two forest masks developed in the framework of international projects; (ii) develop an innovative canopy height model (CHM) through the aggregation of all the major ALS data sets currently available in Italy; (iii) implement an on-line geographic FIS for demonstration purposes, which provides free access to the above two layers. We first give an overview of the available forest maps (local, continental and global) and ALS data sets available for Italy, then we describe the methodology used for preparing the forest mask and the $\mathrm{CHM}$, and finally we introduce the on-line geographic FIS.

\section{Materials}

\section{Study area}

Italy covers $301,338 \mathrm{~km}^{2}$, centered at latitude $42^{\circ} 30^{\prime}$ and longitude $12^{\circ} 30^{\prime}$, and it is divided into 21 local administrations, i.e., Regions and Autonomous Provinces (the Nomenclature of Territorial Units for Statistics [NUTS] level 2, following the European Statistical Office [Eurostat] classification). The country has large climate and geomorphological variability with coastal flat areas, hills and two main mountain chains, the Apennines from North-West to SouthEast, and the Alps in the northern part of the country from West to East, with elevations ranging between 0 and $4800 \mathrm{~m}$ a.s.l. Based on the last Italian NFI statistics (INFC 2007), forests and other wooded lands cover $104,675 \mathrm{~km}^{2}$ (34.7\% of the land area). Forests are dominated by broadleaved species ( $68 \%$ of total forest area), with the presence of 7 out the 14 European Forest Types (Barbati et al. 2014).

\section{Forest mask of Italy}

\section{Forest mask from local maps}

The high resolution forest mask of Italy was created by mosaicking maps of different types. Sixteen high resolution forest maps based on forest types classification systems with a nominal scale varying between 1:5.000 and 1:25.000 were used when available. For five regions we used land use maps based on the Corine Land Cover classification system, and one map (i.e., Sardinia) based on the classification systems of the CORINE Biotopes. All the above maps were produced on the basis of manual photointerpretation of aerial or- 
thophotos between 2000 and 2016.

The maps were downloaded from local on-line geoportals; when multiple versioning for different years were available, we used the version closest to the year 2005, which is the reference year of the Italian NFI (Fig. 1). The details of the local maps used to create the high resolution forest masks are reported in Tab. 1.

\section{Forest masks from international layers}

Although a large number of global or continental forest maps are available, we decided to use only two products provided by JAXA (globally) and COPERNICUS (for Europe), since they officially state to mimic the FAO definition of "forest and other wooded land", which is also adopted by the Italian NFI.

JAXA, for the years 2007, 2008, 2009, 2010, and 2015 provides a forest/non-forest mask in grid format with a $25 \mathrm{~m}$ resolution for the entire globe (JAXA 2016). The JAXA map is produced by automatic processing of multipolarization backscatter signals acquired by the two Synthetic Aperture Radars (SAR), PALSAR and PALSAR 2 (Phased Array type L-band Synthetic Aperture Radar), which are mounted on the two satellites ALOS and ALOS-2 (Advanced Land Observing Satellite). The JAXA map (hereafter named JAXA) was downloaded for the year 2007 from the web repository Earth Engine Data Catalog ${ }^{\circledR}$ (https://developers.google. com/earth-engine/datasets/catalog/JAXA ALOS PALSAR YEARLY SAR).

In the framework of Copernicus Land Monitoring Service (CLMS) coordinated by the European Space Agency (ESA) a forest/ non-forest mask in grid format covering the entire Europe for the years 2012 and 2015 is derived from the FTY, available among the so-called HRL, in which the mainly input sources of the forest layers are Sentinel-2 and Landsat 8 time series, complemented by SPOT- 5 and ResourceSat- 2 satellite data. The FTY map for the year 2012 derived through a spatial intersection of the two primary status layers TCD and DLT (Langanke 2017), was downloaded from https://land.copernicus.eu/pa n-european/high-resolution-layers/forests/f orest-type-1/status-maps/2012. As reported in the metadata, the FTY allows to mimic as close as possible the FAO forest and other wooded land definition. It has an original spatial resolution of $20 \mathrm{~m}$ and consists of two products: (i) a forest types product with a MMU of 0.5 ha, as well as a $10 \%$ tree cover density threshold applied; (ii) a support layer mapping trees under agricultural uses and in urban contexts on the basis of the land uses from the Corine Land Cover (CLC) 2012 project, and the 2012 degree of imperviousness product (available among the $\mathrm{HRL}$ ). In the final $20 \mathrm{~m}$ spatial resolution product that we used, trees predominantly used for agricultural practices and trees in urban context that are distinguished in the forest additional support layer are excluded from the map (Lan-

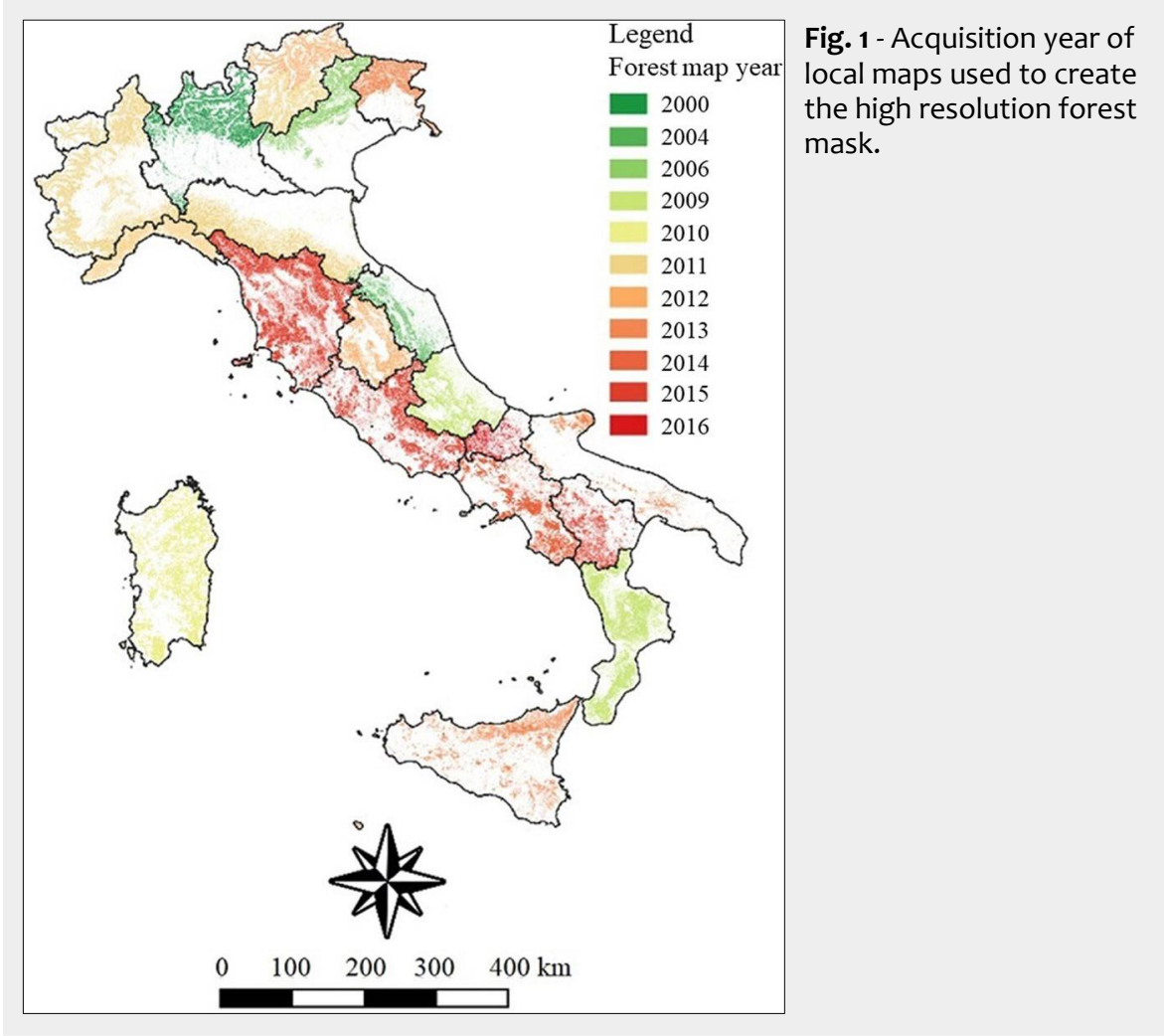

ganke 2017). We referred to this final map as HRL-FM.

thorities currently available in Italy. In total, we found 29 ALS datasets acquired in the period 2004-2017 by 12 local and national different authorities (Tab. 2, Fig. 2). The

Airborne Laser Scanner surveys

We searched for all the ALS data sets col- data are available free of charge, or in lected from local, regional, and national au- some cases can be acquired upon request

Tab. 1 - Main characteristics of local maps used to create the high resolution forest mask.

\begin{tabular}{llclc}
\hline $\begin{array}{l}\text { Administrative } \\
\text { unit }\end{array}$ & Map type & $\begin{array}{c}\text { Production } \\
\text { year }\end{array}$ & Scale & $\begin{array}{c}\text { Minimum } \\
\text { Mapping } \\
\text { Unit (ha) }\end{array}$ \\
\hline Abruzzo & Forest map & 2009 & $1: 10000$ & 0.5 \\
\hline Basilicata & Forest map & 2015 & $1: 10000$ & 0.2 \\
\hline Auton. Prov. of Bolzano & Forest map & 2011 & $1: 25000$ & 0.5 \\
\hline Calabria & Land use map & 2012 & $1: 10000$ & 0.2 \\
\hline Campania & Land use map & 2009 & $1: 25000$ & 0.5 \\
\hline Emilia-Romagna & Land use map & 2014 & $1: 10000$ & 0.2 \\
\hline Friuli Venezia Giulia & Forest map & 2013 & $1: 5000$ & 0.2 \\
\hline Lazio & Forest map & 2011 & $1: 25000$ & 0.5 \\
\hline Liguria & Forest map & 2013 & $1: 25000$ & 0.5 \\
\hline Lombardia & Forest map & 2015 & $1: 10000$ & 0.25 \\
\hline Marche & Forest map & 2000 & $1: 25000$ & 0.5 \\
\hline Molise & Forest map & 2004 & $1: 10000$ & 0.5 \\
\hline Piemonte & Forest map & 2016 & $1: 10000$ & 0.2 \\
\hline Puglia & Forest map & 2011 & $1: 10000$ & 0.25 \\
\hline Sardinia & Land use map & 2013 & $1: 200000$ & 0.5 \\
\hline Sicilia & Forest map & 2010 & $1: 10000$ & 0.5 \\
\hline Toscana & Land use map & 2013 & $1: 25000$ & 0.2 \\
\hline Auton. Prov. of Trento & Forest map & 2015 & $1: 10000$ & 0.2 \\
\hline Umbria & Forest map & 2012 & $1: 25000$ & 0.5 \\
\hline Valle d'Aosta & Forest map & 2011 & $1: 10000$ & 0.5 \\
\hline Veneto & Forest map & 2006 & $1: 10000$ & 0.5 \\
\hline & & & & \\
\hline
\end{tabular}


Tab. 2 - Main characteristics of ALS surveys available in Italy. In the spatial resolution column, "raw data" refers to the availability of point clouds with or without ground/non-ground classification.

\begin{tabular}{|c|c|c|c|c|c|c|c|c|}
\hline ID & Data provider & $\begin{array}{l}\text { Survey } \\
\text { year }\end{array}$ & Survey area & $\begin{array}{l}\text { Coverage } \\
\left(\mathrm{km}^{2}\right)\end{array}$ & $\begin{array}{c}\text { Flight } \\
\text { altitude }(\mathrm{m})\end{array}$ & $\begin{array}{l}\text { Density } \\
\text { (pulse } \mathrm{m}^{-2} \text { ) }\end{array}$ & $\begin{array}{l}\text { Spatial } \\
\text { resolution }(\mathrm{m})\end{array}$ & Sensor \\
\hline 1 & Basilicata & 2013 & Basilicata & 11,072 & 900 & 4 & $5 \times 5$ & Riegl LMS Q680i \\
\hline 2 & $\begin{array}{l}\text { Autonomous Province } \\
\text { of Bolzano }\end{array}$ & $\begin{array}{l}2004- \\
2006\end{array}$ & South Tyrol & 9,682 & $850-1100$ & 0.6 & $2.5 \times 2.5$ & $\begin{array}{l}\text { TopoSys Falcon II and } \\
\text { Optech Gemini ALTM } \\
3033\end{array}$ \\
\hline 3 & Bosco Fontana & 2006 & Bosco Fontana & 4 & - & 5.6 & $1 \times 1+$ raw data & Optech ALTM 3100 \\
\hline 4 & Municipality of Firenze & 2017 & Florence & 102 & 915 & 4 & $1 \times 1$ & Riegl LMS-Q680i \\
\hline 5 & $\begin{array}{l}\text { Autonomous Region of } \\
\text { Fruli Venezia-Giulia }\end{array}$ & $\begin{array}{l}2006- \\
2010\end{array}$ & Fruli Venezia-Giulia & 8,500 & $180-3000$ & 4 & $\begin{array}{l}1 \times 1+\text { classified } \\
\text { raw data }\end{array}$ & $\begin{array}{l}\text { Optech Gemini ALTM } \\
3033\end{array}$ \\
\hline 6 & LaMMA & 2015 & $\begin{array}{l}\text { Tuscany forest } \\
\text { windthrows } 4- \\
5 / 03 / 15\end{array}$ & 513 & 1100 & 4.4 & $\begin{array}{l}1 \times 1+\text { classified } \\
\text { raw data }\end{array}$ & Riegl LMS-Q680i \\
\hline 7 & $\begin{array}{l}\text { MATTM Contracts: } 140 \text {, } \\
145,155,172,204, \\
208\end{array}$ & $\begin{array}{l}2007- \\
2016\end{array}$ & National Rivers & 167,962 & - & - & $1 \times 1+$ raw data & $\begin{array}{l}\text { ALTM Gemini, ALTM } \\
\text { 3100, Pegasus }\end{array}$ \\
\hline 8 & $\begin{array}{l}\text { MATTM Contracts: } 140 \text {, } \\
176\end{array}$ & $\begin{array}{l}2008- \\
2012\end{array}$ & Coast line & 5,917 & - & - & $2 \times 2+$ raw data & $\begin{array}{l}\text { ALTM Gemini, ALTM } \\
3100 \text {, Pegasus }\end{array}$ \\
\hline 9 & Piemonte & $\begin{array}{l}2009- \\
2011\end{array}$ & Piemonte & 25,694 & 4500 & 0.5 & $5 \times 5+$ raw data & $\begin{array}{l}\text { LEICA ALS50-II (Leica } \\
\text { Geosystems 2006) }\end{array}$ \\
\hline 10 & $\begin{array}{l}\text { Autonomous Region of } \\
\text { Sardinia }\end{array}$ & 2008 & Alghero & 67 & 800 & 1 & $5 \times 5$ & Riegl LMS-Q560 \\
\hline 11 & $\begin{array}{l}\text { Autonomous Region of } \\
\text { Sardinia }\end{array}$ & 2008 & Coast & 4,512 & 1400 & 1 & $1 \times 1$ & Optech Gemini ALTM \\
\hline 12 & $\begin{array}{l}\text { Autonomous Region of } \\
\text { Sardinia }\end{array}$ & 2009 & Ogliastra & 512 & 800 & 5 & $1 \times 1+$ raw data & Riegl LMS-Q560 \\
\hline 13 & $\begin{array}{l}\text { Autonomous Region of } \\
\text { Sardinia }\end{array}$ & 2013 & Urban centers & 1,522 & 700 & 4 & $1 \times 1$ & Riegl LMS Q680i \\
\hline 14 & $\begin{array}{l}\text { Toscana, Province of } \\
\text { Arezzo }\end{array}$ & 2004 & Arno, Tevere & 89 & 1200 & $0.5-1.5$ & $2 \times 2$ & $\begin{array}{l}\text { Optech Gemini ALTM } \\
3033\end{array}$ \\
\hline 15 & $\begin{array}{l}\text { Toscana Serchio basin } \\
\text { authority }\end{array}$ & 2005 & $\begin{array}{l}\text { Canale Ozzeri, Rio } \\
\text { Guappero }\end{array}$ & 31 & 1200 & 1 & $1 \times 1$ & $\begin{array}{l}\text { Optech Gemini ALTM } \\
3032\end{array}$ \\
\hline 16 & $\begin{array}{l}\text { Toscana Serchio basin } \\
\text { authority }\end{array}$ & 2006 & $\begin{array}{l}\text { Serchio and main } \\
\text { tributaries }\end{array}$ & 12,435 & 1200 & 1 & $1 \times 1$ & $\begin{array}{l}\text { Optech Gemini ALTM } \\
3033\end{array}$ \\
\hline 17 & Toscana & $\begin{array}{l}2006- \\
2007\end{array}$ & Mugello, Sieve & 305 & 1200 & 1 & $1 \times 1$ & $\begin{array}{l}\text { Optech Gemini ALTM } \\
3033\end{array}$ \\
\hline 18 & $\begin{array}{l}\text { Toscana, Province of } \\
\text { Siena }\end{array}$ & 2007 & Ombrone, Arbia & 35 & 1500 & 1 & $1 \times 1$ & Optech Gemini \\
\hline 19 & $\begin{array}{l}\text { Toscana, Arno basin } \\
\text { authority }\end{array}$ & 2008 & $\begin{array}{l}\text { Elsa, Ombrone, } \\
\text { Bisenzio, Sieve }\end{array}$ & 913 & 1200 & 1.50 & $1 \times 1$ & ALTM Gemini \\
\hline 20 & $\begin{array}{l}\text { Toscana, Arno basin } \\
\text { authority }\end{array}$ & 2008 & Monti della Calvana & 314 & 2300 & 0.40 & $3 \times 3$ & ALTM Gemini \\
\hline 21 & $\begin{array}{l}\text { Toscana, Arno basin } \\
\text { authority }\end{array}$ & 2009 & Monti della Calvana & 314 & 2300 & 0.40 & $2 \times 2$ & ALTM Gemini \\
\hline 22 & Toscana & 2010 & $\begin{array}{l}\text { Lunigiana, Pistoia, } \\
\text { Lucca, Scarlino }\end{array}$ & 1,923 & - & 0.50 & $1 \times 1$ & $\begin{array}{l}\text { Optech Gemini ALTM and } \\
\text { Optech Pegasus ALTM }\end{array}$ \\
\hline 23 & Toscana & 2011 & Aulla & 85 & $1800-1900$ & 0.5 & $1 \times 1$ & Optech Gemini \\
\hline 24 & Toscana & 2012 & $\begin{array}{l}\text { Carrara, Pienza, } \\
\text { Minucciano, Vagli }\end{array}$ & 101 & 1600 & 1.7 & $1 \times 1$ & $\begin{array}{l}\text { Optech Gemini ALTM and } \\
\text { Optech Pegasus ALTM }\end{array}$ \\
\hline 25 & Toscana & 2012 & Magra & 54 & 1400 & 1.5 & $1 \times 1$ & Optech Pegasus \\
\hline 26 & Toscana & 2012 & $\begin{array}{l}\text { Teglia, Osca, } \\
\text { Mangiola }\end{array}$ & 26 & 1050 & 1.5 & $1 \times 1$ & Optech Gemini \\
\hline 27 & $\begin{array}{l}\text { Autonomous Province } \\
\text { of Trento }\end{array}$ & 2006 & $\begin{array}{l}\text { Trentino excluded } \\
\text { Adige river }\end{array}$ & 6,516 & $1000-1800$ & 1.8 & $1 \times 1+$ raw data & Optech ALTM 3100 \\
\hline 28 & $\begin{array}{l}\text { Autonomous Province } \\
\text { of Trento }\end{array}$ & 2009 & Adige river & 550 & 1500 & 0.5 & $1 \times 1+$ raw data & TopoSys \\
\hline 29 & $\begin{array}{l}\text { Autonomous Region } \\
\text { of Valle d'Aosta }\end{array}$ & 2008 & Valle d'Aosta & 3,264 & $2700-4700$ & 2 & $2 \times 2+$ raw data & Optech Gemini ALTM \\
\hline
\end{tabular}

to the owner or after payment of storage rivers for hydraulic risk assessment.

fees. The largest dataset was collected by the Italian Ministry of Environment (MATTM), which acquired ALS data at national level along the Italian coast and
The remaining datasets were acquired by Regions and other local authorities (i.e., municipalities, provinces, catchment management authorities, and research institu- tions). In some areas multitemporal acquisitions were also available, mainly located in Regions with wide local ALS coverage where multiple MATTM surveys were carried out. The Regions with multitemporal 
Fig. 2 - ALS data sets available in Italy by data provider (left panel) and year of acquisition (right panel).

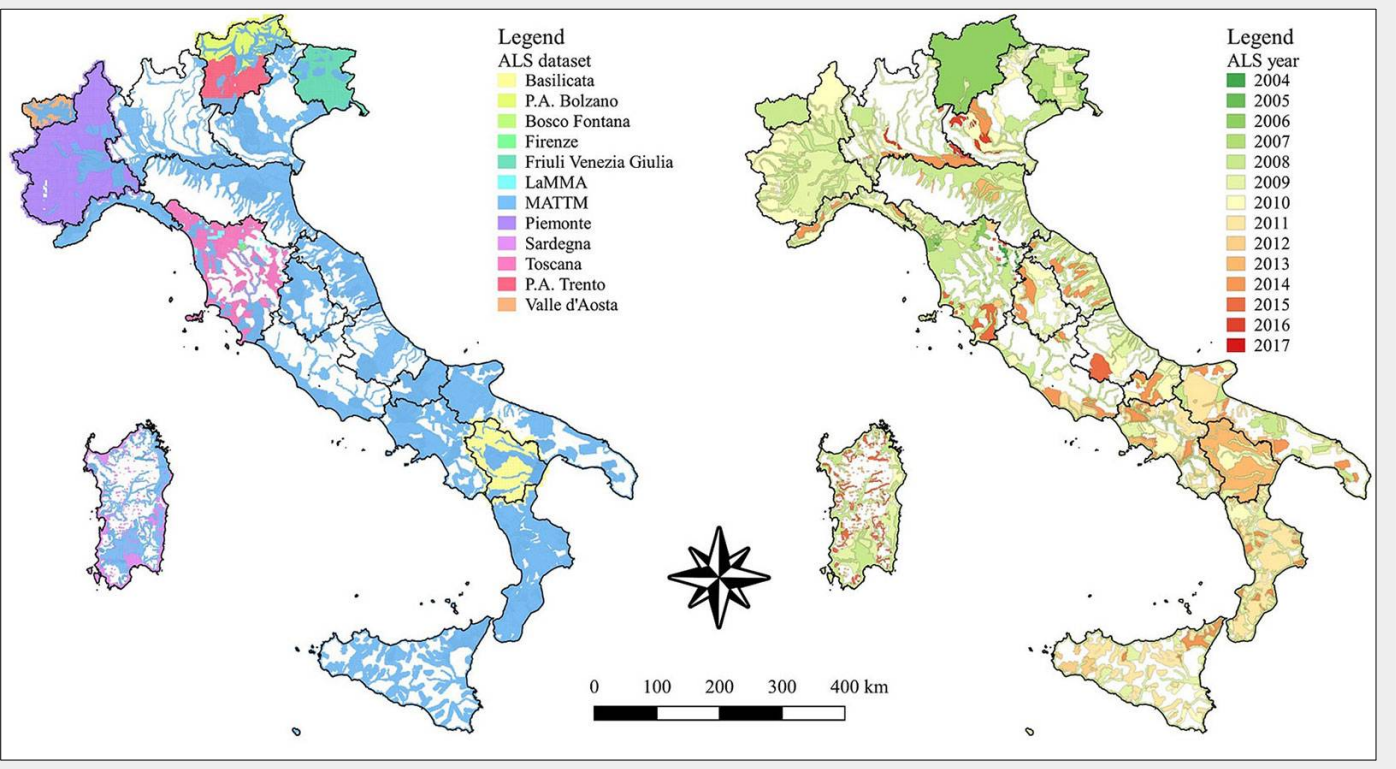

data sets are Liguria (covering $49 \%$ of the Region), Valle d'Aosta (40\%), Molise (36\%), Piemonte (33\%), Trentino Alto-Adige (32\%), Basilicata (26\% - Fig. 2). In several Regions new ALS dataset are either under acquisition or have been already acquired but still not distributed.

Tab. 2 reports the main characteristics of ALS data sets used in this study. It is worth noting that in some cases point clouds were collected as raw or classified data, while for some data sets we collected only pre-processed data such as raster grid Digital Terrain Models (DTMs), which provide the elevation of the ground terrain, and Digital Surface Models (DSM), which provide the elevation of the earth surface including trees, buildings, and other features above the ground.

\section{Italian National Forest Inventory \\ reference data}

The $2^{\text {nd }}$ Italian National Forest Inventory (INFC 2007) is based on a three-phase, nonaligned, systematic sampling design, with results referred to the year 2005 . More details on the Italian NFI are reported in Fattorini et al. (2006) and Chirici et al. (2020).

To assess the accuracy of the forest masks we used the official estimates of total forest area (i.e., forest + other wooded land) aggregated at national (NUTS1), regional (NUTS2), and province levels (NUTS3 - INFC 2007). Such estimates are freely available on line at https://www.sian. it/inventarioforestale/.

\section{Italian national grids}

Resampling all the different layers (forest masks and ALS data sets) to produce a harmonized spatial datasets with a common spatial extension and resolution is a standard procedure when maps have to be compared with the information collected in the NFIs (Kangas et al. 2018).

For this study we generated two reference grids for Italy, both projected using the coordinate system WGS 84 / UTM zone 32 North (EPSG:32632), at two different resolutions: $1 \mathrm{~m}$ and $23 \mathrm{~m}$. The tessellation at $23 \mathrm{~m}$ was chosen to mimic the size of the field plots measured in the Italian NFI (Chirici et al. 2020), and this generated a total of $569,769,690$ cells. Following this approach all the raster layers potentially included in the geographical FIS should be resampled to the same $23 \mathrm{~m}$ resolution.

The $23 \mathrm{~m}$ resolution cells were then subdivided to achieve the $1 \mathrm{~m}$ grid, consisting of $301,408,166,010$ cells, which were used for the subsequent harmonization process of local forest maps.

\section{Methods}

\section{Forest mask}

\section{Harmonization of local forest maps}

The local forest maps were all re-projected using the same coordinate system (WGS 84 / UTM zone 32 North, EPSG: 32632), merged and rasterized as grid layers using the national grid with $1 \times 1 \mathrm{~m}$ spatial resolution, and reclassified into Boolean masks using " 1 " for pixels classified as "forest", and the "o" for pixels classified as "non-forest". The term "forest" is hereinafter intended as "forest and other wooded areas", according to the FAO definition.

Since the different local maps were developed at different resolutions, a simple procedure was applied to harmonize all the maps to the FAO forest definition based on the minimum tree cover of $5 \%$.

The forest cover ratio $\left(F_{\mathrm{i}}\right)$ was then calculated for each $23 \times 23 \mathrm{~m}$ cell as follows (eqn. 1):

$$
F_{i}=\frac{\sum_{i=1}^{n} y_{i}}{n} \cdot 100
$$

where $y_{\mathrm{i}}$ is the number of forest pixels re- sulting from the $1 \times 1 \mathrm{~m}$ forest mask, and $\mathrm{n}$ $=529$, i.e., the total number of $1 \times 1 \mathrm{~m}$ pixels within the $23 \times 23 \mathrm{~m}$ pixels.

All the $23 \times 23 \mathrm{~m}$ cells with $F_{\mathrm{i}} \geq 5 \%$ were classified as "forests", while the remaining cells were classified as "non-forest". After the merging process we obtained a national layer hereinafter identified as REGFM (REGional Forest Mask).

For comparison purposes, the JAXA and HRL maps were resampled from their original resolution (25 and 20 meters, respectively) to the $23 \mathrm{~m}$ national grid and Boolean maps of forest cover were created following the methodology described above.

The results are the three national raster forest masks REG-FM, JAXA-FM, and HRL$F M$ with the spatial resolution of the national grid at $23 \times 23 \mathrm{~m}$.

\section{Accuracy assessment of the forest masks}

To assess the accuracy of the three forest masks (REG-FM, JAXA-FM, and HRL-FM) we used as benchmark the forest area reported by the official statistics of the $2^{\text {nd }}$ Italian NFI (INFC 2007). For each national forest mask, we computed the forest area for all Italy (NUTS1), for 20 Regions (administrative units at NUTS2 level, considering the Autonomous Provinces of Trento and Bolzano as a unique Region) and 103 Provinces (administrative units at NUTS3 level).

For each administrative unit we computed the percentage difference (diff\%) between the official NFI forest area estimate, and the forest area derived from the different forest masks as follows (eqn. 2):

$$
\operatorname{diff}_{\%}=\frac{A_{\text {mask }}-A_{N F I}}{A_{N F I}}
$$

where $A_{\text {mask }}$ is the forest area calculated based on the forest masks (REG-FM, JAXA$F M, H R L-F M)$, and $A_{\mathrm{NFI}}$ is the forest area provided by official NFI statistics.

We also calculated the coefficient of determination $\left(R^{2}\right)$, and the root mean square error, both as absolute (RMSE) and relative 
values $\left(\mathrm{RMSE}_{\%}\right)$ against the $A_{\mathrm{NF}}$, between NFI statistics and the forest area from the different forest masks as follows (eqn. 3 , eqn. 4):

$$
\begin{aligned}
& R M S E=\frac{\sqrt{\sum_{i=1}^{n}\left(A_{\text {mask }_{i}}-A_{N F I_{i}}\right)^{2}}}{n} \\
& R M S E_{\%}=\frac{R M S E}{A_{N F I}}
\end{aligned}
$$

where $A_{\text {mask } i}$ is the forest area calculated on the basis of the forest masks in the $i$-th administrative unit, $A_{\mathrm{NFI} i}$ is the forest area provided by official NFI statistics for the $i$ th administrative unit, $n$ is the number of administrative units. Finally, the forest area estimates from the NFI for the same administrative units were calculated, along with their estimated standard error.

\section{Italian National CHM}

The available ALS datasets were derived from several flight campaigns and were provided with different specifications and formats. Therefore, the generation of a homogeneous $\mathrm{CHM}$ required specific pre-processing steps depending of data characteristics.

For those ALS datasets where raw data were available (IDs 3, 5, 9, 12, 27, 28 - Tab. 2) we firstly classified the ALS point clouds and then we produced DTMs and DSMs.
Using the software LasTools ${ }^{\circledast}$ (Isenburg 2017) errors in returns were eliminated with the "lasnoise" algorithm, and the pulses corresponding to ground and nonground were classified with "lasground" and "lasclassify" procedures. The 1-m resolution DTM from ground pulses and the DSM from non-ground pulses were generated with the adaptive TIN model algorithm using the procedure "las2dem" in LasTools ${ }^{\oplus}$.

For those datasets where point clouds were not available (IDs 1, 2, 8, 10, 14, 20, 21, 29 - Tab. 2), and DTM and DSM were at a resolution different from $1 \mathrm{~m}$, the datasets were resampled using a cubic convolution.

The remaining dataset (IDs 4, 6, 7, 11, 13, $15,16,17,18,19,22,23,24,25,26$ - Tab. 2) had already a $1-\mathrm{m}$ resolution, thus were not resampled.

The $1-\mathrm{m}$ resolution $\mathrm{CHM}$ was computed by subtracting the DTM from the DSM in the coordinate reference system WGS 84 / UTM zone 32 North (EPSG:32632). Lastly, for each $23 \times 23 \mathrm{~m}$ cell of the national grid the mean value from the $1-\mathrm{m}$ resolution $\mathrm{CHM}$ was calculated.

\section{Results}

\section{Forest mask (REG-FM)}

Based on the forest mask obtained from the aggregation of local forest maps (REGFM), the total area of forest and other wood lands resulted of $102,610.9 \mathrm{~km}^{2}(34 \%$ of land area of Italy), which is $1.9 \%$ less than the estimated official statistics reported in the $\mathrm{NFI}\left(104,675.33 \mathrm{~km}^{2}\right.$, with an estimated standard error of $0.3 \%)$. Both the other two forest masks (JAXA-FM and HRL-FM) were less consistent with $\mathrm{NFI}$ estimates. Using JAXA-FM the forest area estimate obtained was $100,177.8 \mathrm{~km}^{2}$ (33.2\% of land area), with an underestimation of almost $4 \%$ compared to NFI data; using HRL-FM we obtained a total forest area of $112,133.1 \mathrm{~km}^{2}$ (37.2\% of land area), with an overestimation of approximately $16 \%$ when compared to NFI estimates (Tab. 3).

The REG-FM forest mask resulted the most accurate also at Regional (NUTS2) and Province (NUTS3) level. For NUTS2 we found that REG-FM matches the NFI estimates better than other masks in 11 out of 20 Regions, versus 6/20 regions of HRL-FM, and 3/20 of JAXA-FM (Tab. 3). Using REGFM the largest understimations of forest area were detected for Marche $(-15 \%)$ and Sardinia $(-26 \%)$, while the largest overestimations was in Sicily (+52\%) and Calabria $(+28 \%)$. As for the NUTS3 level, the REG-FM yielded the best estimates in 50 Provinces out of 103 , versus $28 / 103$ with HRL-FM and 25/103 with JAXA-FM. The REG-FM at Province level showed a performance to that registered at Regional level, with strong overestimations in Puglia, Sicily, and Calabria, and underestimations in Lombardy,

Tab. 3 - Accuracy assessment of different national forest masks (REG-FM, JAXA-FM, HRL-FM) at NUTS1 (country) and NUTS2 (regions) levels. The forest and other wooded land area and the percentage difference (Diff\%) are reported for each forest masks.

\begin{tabular}{|c|c|c|c|c|c|c|c|c|}
\hline \multirow{2}{*}{ NUTS } & \multirow{2}{*}{ Area } & \multicolumn{3}{|c|}{ Forest and other wooded land area $\left(\mathrm{km}^{2}\right)$} & \multicolumn{3}{|c|}{ Diff\%(\%) } & \multirow{2}{*}{$\begin{array}{l}\text { NFI forest area } \\
\left(\mathrm{km}^{2}\right) \text { and } \mathrm{ES} \%\end{array}$} \\
\hline & & REG & JAXA & HRL & REG & JAXA & HRL & \\
\hline NUTS1 & Italy & 102610.9 & 100177.8 & 112133.1 & -2 & -4 & 7 & $104675.30(0.3)$ \\
\hline \multirow{20}{*}{$\begin{array}{l}\text { NUTS2 } \\
\text { (Regions) }\end{array}$} & Abruzzo & 4556.03 & 3913.81 & 5118.1 & 4 & -11 & 17 & $4385.90(1.3)$ \\
\hline & Basilicata & 3239.48 & 2402.19 & 3216.77 & -9 & -33 & -10 & $3564.27(1.5)$ \\
\hline & Calabria & 7841.35 & 6211.36 & 6715.52 & 28 & 1 & 10 & $6129.31(1.1)$ \\
\hline & Campania & 4460.5 & 4644.41 & 5942.53 & 0 & 4 & 33 & $4452.75(1.5)$ \\
\hline & Emilia-Romagna & 6202.72 & 6026.12 & 6915.4 & 2 & -1 & 14 & $6088.17(1.2)$ \\
\hline & Friuli Venezia Giulia & 3244.71 & 3473.43 & 3531.78 & -9 & -3 & -1 & $3572.24(1.3)$ \\
\hline & Lazio & 6200.5 & 6624.49 & 6849.31 & 2 & 9 & 13 & $6058.59(1.2)$ \\
\hline & Liguria & 3925.8 & 4692.92 & 3963.49 & 5 & 25 & 6 & $3751.34(1.1)$ \\
\hline & Lombardia & 6203.02 & 8487.41 & 7029.52 & -7 & 27 & 6 & $6657.01(1.2)$ \\
\hline & Marche & 2618.61 & 2452.51 & 3304.99 & -15 & -20 & 7 & $3080.76(1.6)$ \\
\hline & Molise & 1583.44 & 1038.26 & 1847.08 & 7 & -30 & 24 & $1486.40(2.3)$ \\
\hline & Piemonte & 9326.76 & 11266.29 & 10165.41 & -1 & 20 & 8 & $9401.15(1.0)$ \\
\hline & Puglia & 1735.28 & 1749.27 & 4390.04 & -3 & -2 & 145 & $1790.40(2.6)$ \\
\hline & Sardinia & 8943.82 & 5636.15 & 9115.8 & -26 & -54 & -25 & $12132.51(0.8)$ \\
\hline & Sicilia & 5134.48 & 2082.68 & 3941.15 & 52 & -38 & 17 & 3381.71 (1.9) \\
\hline & Toscana & 11687.77 & 11645.15 & 12626.22 & 1 & 1 & 10 & $11515.38(0.7)$ \\
\hline & Trentino-Alto Adige & 7503.17 & 7958.62 & 7311.26 & -4 & 2 & -6 & 7797.05 (1.2) \\
\hline & Umbria & 3411.15 & 3400.31 & 4160.79 & -13 & -13 & 7 & $3902.55(1.2)$ \\
\hline & Valle d'Aosta & 981.06 & 1435.56 & 966.31 & -7 & 36 & -9 & $1059.28(2.7)$ \\
\hline & Veneto & 4131.19 & 5036.88 & 5021.65 & -8 & 13 & 12 & $4468.56(1.4)$ \\
\hline
\end{tabular}
The forest area and its standard error (ES\%) from NFI are also reported. 
Veneto, Basilicata, and Sardinia.

The $\mathrm{R}^{2}$ and RMSE statistics confirmed these results. For Regions (NUTS2) and Provinces (NUTS3) the REG-FM appeared the best performing forest masks, with $\mathrm{R}^{2}=$ 0.91 and RMSE $=19 \%$ and $R^{2}=0.95$ and RMSE $=23 \%$ for NUTS2 and NUTS3, respectively. HRL-FM and JAXA-FM ranged between 0.80 and 0.90 in terms of $R^{2}$, and between $21 \%$ and $40 \%$ in terms of RMSE (Tab. 4, Fig. 3).

\section{Italian National CHM}

As a result of mosaicking the ALS data sets, we produced a $23-\mathrm{m}$ resolution $\mathrm{CHM}$ over an area of $191,076.52 \mathrm{~km}^{2}$, which covers $63 \%$ of the Italian territory, and includes $59 \%$ of the Italian forest area (based on the REG-FM - Fig. 4). Most of ALS data were acquired between the years 2008 and 2011 (68\% of the total area covered by ALS data - Fig. 5).

At Regional level (NUTS2) the CHM fully covers the forest area of 4 Regions: Trentino-Alto Adige, Friuli Venezia Giulia, Basilicata, and Valle d'Aosta. In three more Regions, i.e., Piemonte, Calabria and Liguria, the forest area is almost fully included, with $99 \%$, $91 \%$, and $86 \%$ coverage, respectively. Emilia-Romagna was the region with the lowest percentage of the forest area covered by the CHM (only $7 \%$ ), followed by Lombardy (21\%), Lazio (23\%), and Marche (37\% - Fig. 6).

\section{Forest Information System web-GIS infrastructure}

The harmonized geographic layers described above are available online through an open access web-GIS service representing a possible example of a future geographic Forest Information System. The platform has a user-friendly interface allowing to view and query the Italian $\mathrm{Na}$ tional Forest Mask and the national $\mathrm{CHM}$
Tab. 4 - RMSE, RMSE\%, and $R^{2}$ for the three forest masks (REG-FM, JAXA-FM, HRL-FM) at NUTS3 (Province) and NUTS2 (Region) levels.

\begin{tabular}{lcccccc}
\hline \multirow{2}{*}{ Mask } & \multicolumn{2}{c}{ RMSE (ha) } & \multicolumn{2}{c}{ RMSE\% } & \multicolumn{2}{c}{ R $^{2}$} \\
\cline { 2 - 7 } & Province & Region & Province & Region & Province & Region \\
\hline HRL & 24,943 & 112,940 & 24 & 21 & 0.93 & 0.90 \\
\hline JAXA & 41,340 & 154,774 & 40 & 29 & 0.82 & 0.80 \\
\hline REG & 23,254 & 103,133 & 23 & 19 & 0.95 & 0.91 \\
\hline
\end{tabular}

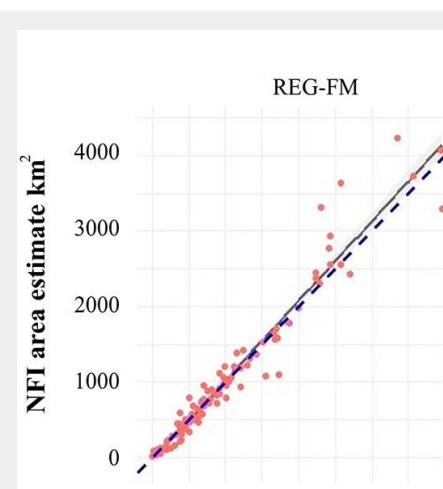

\section{Correlation at NUTS3 level} JAXA-FM

HRL-FM

$\begin{array}{lllllllllllllll}0 & 1000 & 2000 & 3000 & 4000 & 0 & 1000 & 2000 & 3000 & 4000 & 0 & 1000 & 2000 & 3000 & 4000\end{array}$ Mask area $\mathrm{km}^{2}$

\section{Correlation at NUTS2 level}

REG-FM JAXA-FM

HRL-FM
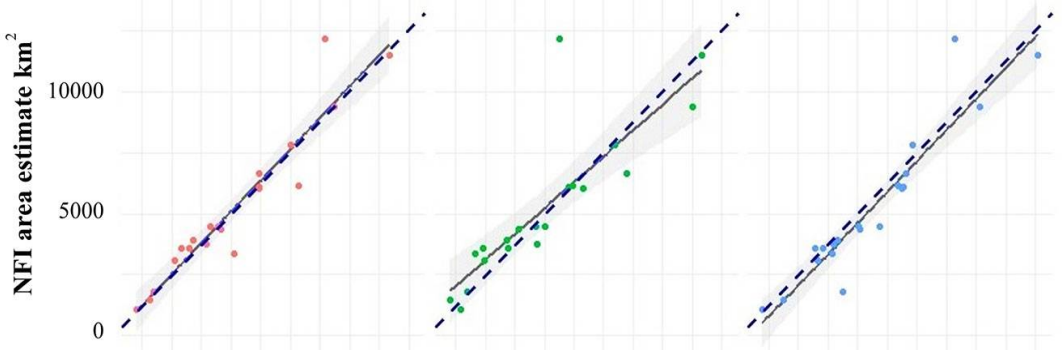

$2500500075001000012500 \quad 2500500075001000012500 \quad 2500500075001000012500$ Mask area $\mathbf{k m}^{2}$

Fig. 3 - Correlation between the forest area estimates derived from the different forest masks (REG-FM, JAXA-FM, HRL-FM) and the NFI estimates at NUTS2 (Region) and NUTS3 (Province) level. The dotted blue line is the $y=x$ line.

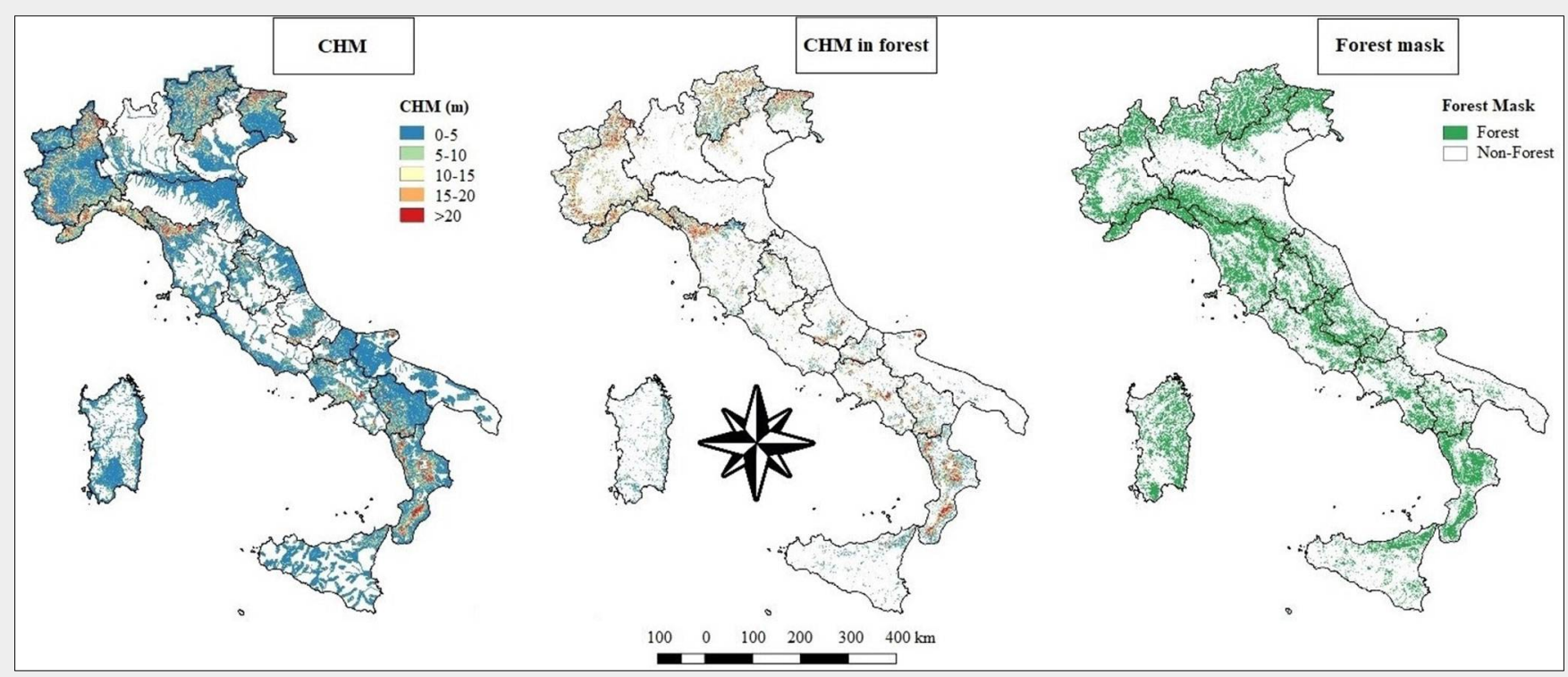

Fig. 4 - (left panel): The CHM generated in this study; (middle panel): the forest area covered by the CHM ( $59 \%$ of the whole forest area); (right panel): the high-resolution nationwide forest mask developed in this study (REG-FM). 


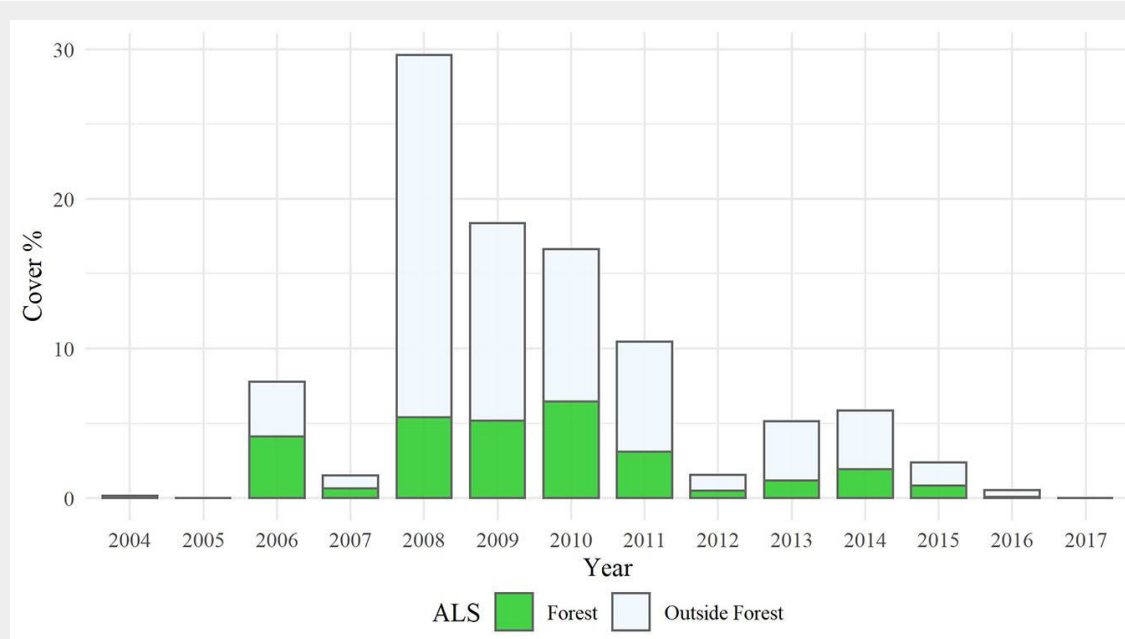

Fig. 5 - Yearly distribution of the area covered by local ALS surveys in Italy.

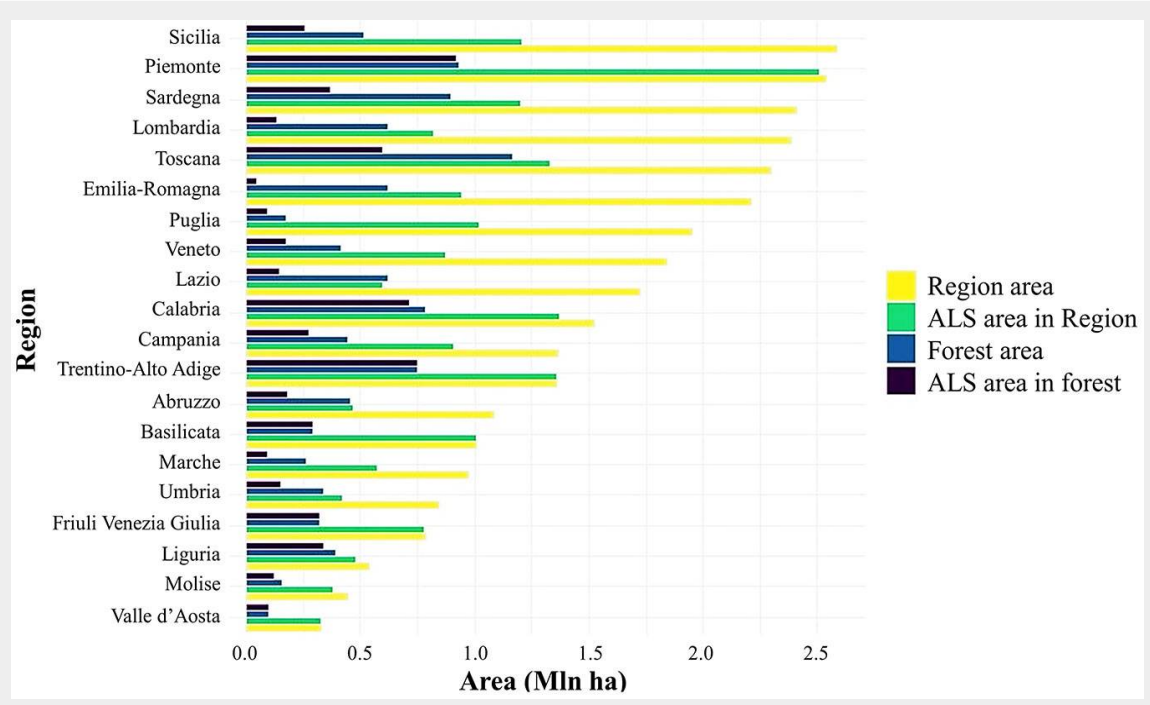

Fig. 6 - Area covered by local ALS surveys in each Italian Region.

developed in this study. The platform is designed to be scalable and is updated constantly. The first version of the web-GIS platform is available at http://forestinfo.it (Fig. 7).

Through the web-GIS, users can interact with the two above data sets (REG-FM and national $\mathrm{CHM}$ ), though at the moment they cannot be downloaded. The whole platform was developed using free, opensource geospatial libraries. The web-GIS is based on GeoServer ${ }^{\circledast}$ (Java - http://geoserv er.org/) and Lizmap ${ }^{\circledast}$ (https://www.3liz. com) with data stored in a PostgreSQL database, implemented with the extension PostGIS, which allows to select data by query and create customized maps. The web-GIS was structured to allow to manage data independently from data processing. The web platform was designed to host both raster and vector layers.

\section{Discussion}

In this study we presented: (i) the creation of a new high resolution Italian $\mathrm{Na}$ tional Forest Mask (REG-FM) developed by combining local forest maps; the mask was evaluated against the aggregated forest area estimates derived from the Italian NFI and was compared with two other forest masks based on radar remotely sensed data available globally (JAXA-FM) and for Europe by the COPERNICUS services on the basis of optical imagery (HRL-FM); (ii) a new national high-resolution $\mathrm{CHM}$ derived from harmonized datasets at local scale available in Italy; and (iii) the first national forest web-GIS, a platform designed to store and navigate through geographic forest layers. Overall, the size of data collected for this study over three years amount to 24.7 terabytes.

The major problem encountered in the construction of the Italian National Forest Mask (REG-FM) from local forest maps was related to the different forest definitions and classification systems used by the different local Authorities (Tab. 1). In fact, REG-FM was obtained by merging 20 local forest maps (considering the Autonomous Provinces of Trento and Bolzano as a unique Region) created by photointerpretation. Among these, 12 maps used the FAO forest definitions, and 8 the regional forest definitions. For these reasons, the first step of this study was aimed at harmonizing the different forest maps and discarding those forest areas that did not match the FAO definition of forest and other wooded land. In general, the results revealed that REGFM is more congruent with NFI forest area estimates than JAXA-FM and HRL-FM, at any of the considered spatial scales (i.e., NUTS1, NUTS2 and NUTS3). This was true especially for northern and central Italy, as REG-FM showed more consistent deviations from NFI estimates in the southern regions (i.e., Sardinia, Sicily, Calabria, Basilicata, and Puglia). Such discrepancies can
Fig. 7 - Forest Information System webGIS interface (http:// forestinfo.it).
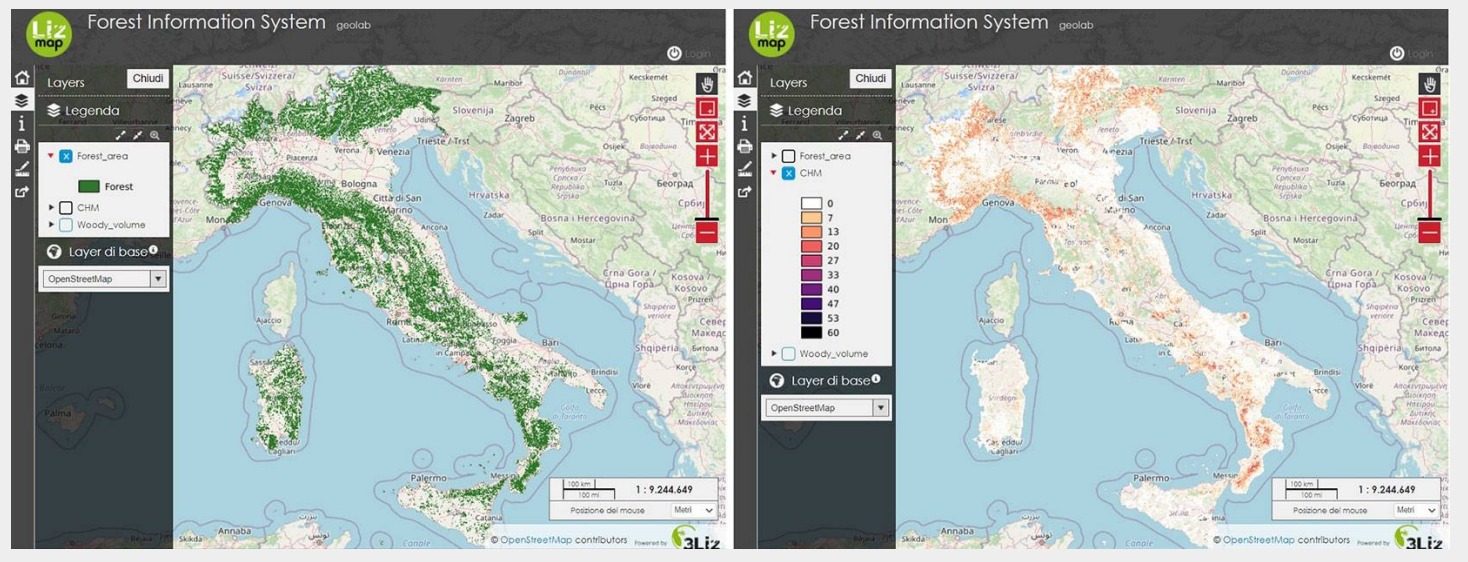
be due to the large presence in these Regions of olive groves, orchards, and abandoned pastures or crops with sparse tree coverage, which can be easily confused with other forest types or shrubby formations typical of the Mediterranean "macchia". For example, using the HRL-FM in Puglia most of the olive groves were classified as forest, leading to a discrepancy of $145 \%$ between HRL-FM and NFI estimates.

Overall, the average difference in forest area estimates between REG-FM and NFI official statistics across regions was about $0.6 \%$, with differences $\geq 10 \%$ for Sicily $(+52 \%)$, Calabria (+28\%), Sardinia (-26\%), Marche $(-15 \%)$ and Umbria (-13\%). It is important to note that the larger differences were observed for those Regions where NFI had larger standard errors (between 1.1\% and 1.9\% - INFC 2007).

For Sardinia, such discrepancies may partly be attributed to the classification system used to develop the local map, which is targeted on habitat types and not specifically on forests. In addition, such map has a very small nominal scale (1:200.000), which is not consistent with a minimum mapping unit of 0.5 ha that should be adopted to be consistent with the FAO forest definition. Finally, in this region forests and other wooded lands are frequently characterized by different types of Mediterranean macchia that is complex to classify through remotely sensing data, even by manual photointerpretation (Hüttich et al. 2014). However, large discrepancies between forest area estimates in Sardinia were also observed using JAXA-FM and HRL-FM maps. In the northern Regions, the forest area derived from the HRL-FM map was typically underestimated when compared to $\mathrm{NFI}$ statistics (from - $0.8 \%$ of Piemonte to $-9 \%$ of Friuli Venezia Giulia - Tab. 3). This is likely due to the presence of numerous high-altitude forest edges, with tree cover between $5 \%$ and $10 \%$ where the transition between shrublands, bushlands or other wooded lands is difficult to assess by photo interpretation. It should be noted that many northern Italian regions do not use a specific class for other wooded land in their nomenclature systems, hampering the harmonization of these maps.

The satellite-derived forest masks (JAXAFM and HRL-FM) showed to be less accurate than the REG-FM, especially in the southern Regions, but with different performances. The JAXA-FM underestimated the forest area in the southern Regions where the forest is characterized by low vegetation and a limited accumulation of growing stock volume, most probably because the relatively poor sensibility of SAR backscatter in HV-polarization (JAXA 2016) in detecting these vegetation types (Hüttich et al. 2014, Bartsch et al. 2020). The HRL-FM overestimated the forest area at all the considered spatial scales, though the vegetation in urban and agricultural contests was masked out with the Copernicus Forest Additional Support Layer. This procedure may be a possible source of error since it is based on two other maps: the 2012 Imperviousness Degree layer, available among the HRL, and the CLC 2012. Both the above maps may be source of errors, especially if we consider the MMU of 25 ha adopted by the Corine Land Cover map, which is probably too coarse to capture the fragmented mosaic of the Italian landscape. For more details on the Imperviousness Degree layer and the Forest Additional Support Layer, see Langanke (2017).

Despite the limitations found for some Italian Regions, our results show that REGFM is the national forest mask most congruent with the forest area estimates of the Italian NFI. The Italian National Forest Mask could be useful for several applications, e.g., to create wall-to-wall spatial estimates of forest variables (Chirici et al. 2020), to mask out non-forest areas when monitoring forest disturbances from clearcuts (Giannetti et al. 2020, Francini et al. 2020) or windthrow damages, as well as for studying forest fragmentation and ecological networks at national scale level.

As already mentioned, a wall-to-wall coverage of ALS data is still missing for Italy (Chirici et al. 2020) and a full catalogue of the main ALS data acquisitions and their extension was also unavailable so far. To the best of our knowledge, this is the first study reporting an exhaustive description of the ALS data currently available in Italy. Moreover, ALS data sets collected by different authorities share some common characteristics which are considered suitable for forestry applications (Goodwin et al. 2006, Wulder et al. 2008): flight altitudes of the acquisition between $500 \mathrm{~m}$ and $3000 \mathrm{~m}$; spatial resolution of derived DTM and DSM raster ranging between $1 \mathrm{~m}$ and $5 \mathrm{~m}$; pulse density between 0.4 and 5 pulses $\mathrm{m}^{-2}$. Low-pulse ALS (0.4-1.0 pulses $\mathrm{m}^{-2}$ ) usually aimed at the creation of digital elevation models (DTM or DSM) still allow a reliable estimation of typically forest structure metrics at the plot level $(\sim 23 \mathrm{~m}$ pixel size - Jakubowski et al. 2013).

Most of the ALS data considered in this study were acquired during three years, i.e., 2008 (18.4\%), 2009 (17.6\%), and 2010 (21.9\%). Several studies demonstrated that a lag time larger than 5 years between field measures and ALS data can be problematic when ABA approach is used to estimate forest variables (Wulder et al. 2008, Tompalski et al. 2019). These means that when the new NFI data for 2015 will be available, most of the currently existing ALS data will be outdated.

In addition to new ALS surveys, new data should be considered for future applications and implementations nationwide, such as those from the NASA's Global Ecosystem Dynamics Investigation (GEDI) mission, which is a waveform LiDAR sensor mounted on the International Space Station, designed to provide a sample of ground-based and canopy LiDAR metrics for large-scale analysis in the Mediterra- nean forests as well (Dubayah et al. 2020). The availability of the two national geographic layers obtained in this study will allow the possibility of producing additional national forest layers. For example, it will be possible to derive spatial estimation of $\mathrm{NFI}$ forest variables using model-assisted estimators, which require the availability of a forest mask (McRoberts et al. 2014, Mura et al. 2016, Bottalico et al. 2017, Chirici et al. 2020) or hierarchical models, which are specifically designed to use partial $\mathrm{CHM}$ coverage (Saarela et al. 2016). Moreover, these layers can be used to study forest structure (Wulder et al. 2008, Valbuena et al. 2013, Mura et al. 2016, Bottalico et al. 2017), species characterization (Maltamo et al. 2015), habitat modeling (Vihervaara et al. 2015), or mapping forest disturbances using optical remote sensing data (Giannetti et al. 2020, Francini et al. 2020).

To ensure a wide use of the two national layers, and other forest layers that will be released in the future, a FIS web-GIS platform was developed. The platform has free access and allows users to perform query on specific areas of interest using maps consistent and aligned with a national grid with cell size of $23 \times 23 \mathrm{~m}$. Expected future improvement of the FIS web-GIS are: the implementation of additional tools specifically designed for forest applications to overcome the limitation of the regional geo-portal, which are usually designed just for cartographic purposes; the release of additional national forest geographic layers, such as the growing stock volume map based on NFI data (Chirici et al. 2020).

Finally, it is important to note that the availability of national spatial forest data sets such as forest/non-forest mask, forest types, forest roads, and growing stock volume is a basic requirement to develop precision forestry applications (Corona et al. 2017) and forest decision support systems at national level, similar to those already tested at regional scale in Italy to support forest planning and management (Puletti et al. 2017), and to map and value forest ecosystem services (Vizzarri et al. 2017).

\section{Conclusion}

We generated the first high resolution forest mask of Italy (REG-FM) by combining local forest and land use maps. Although the original input data sets were created with different forest definitions and at different dates, the resulting forest mask undestimated for less than $2 \%$ the official NFI estimation of the total forest area.

The REG-FM resulted more congruent with NFI statistics than forest masks based on radar (JAXA-FM) and optical (HRL-FM) imagery at national level. However, in some Regions and Provinces the REG-FM was affected by large discrepancies, most probably for a mix of different causes (differences in forest definitions, characteristics of the vegetation especially in Mediterranean macchia and on forest edges). This 
indicates that the REG-FM cannot be currently adopted as an official layer for reporting purposes and an operational revision of REG-FM by manual photointerpretation is required.

The harmonized CHM produced by combining all the ALS data sets currently available in Italy covers only the $59 \%$ of Italian forests and will be soon outdated. These kind of data are essential for forest monitoring and should be routinely acquired together with aerial images.

We implemented an online freely available FIS web-GIS to share this information to all the potential stakeholders (i.e., forest owners, managers, and technicians of local and national administrations). We hope that this could encourage the launch of an operational project for implementing an online National Geographic Forest Information System in Italy. We also recommend that the different forest mapping and monitoring programs currently active in Italy converge on a common nomenclature system, thus facilitating the production of harmonized maps (Chiavetta et al. 2016). For this purpose, we suggest the adoption of the European Forest Types nomenclature systems (Barbati et al. 2014), which covers all the extant forest types in Italy. Lastly, we hope for both NFI data and the exact coordinates of the measured plots to be publicly released by the Italian NFI in the framework of the $3^{\text {rd }}$ National forest inventory, to support the development of future forest maps with ABA approach, such as those of growing stock volume or biomass. Finally, we strongly suggest the evolution of the Italian NFI program into a permanent monitoring system, in order to update the ground data over a period of 5-10 years by visiting a sub-sample of the field plots each year, as it is currently done in other EU and non-EU NFI programs.

\section{References}

Alberdi I, Cañellas I, Vallejo Bombín R (2017). The Spanish national forest inventory: history, development, challenges and perspectives. Pesquisa Florestal Brasileira 37: 361. - doi: 10.4336/ 2017.pfb.37.91.1337

Barbati A, Marchetti M, Chirici G, Corona P (2014). European forest types and Forest Europe SFM indicators: tools for monitoring progress on forest biodiversity conservation. Forest Ecology and Management 321: 145-157. doi: 10.1016/j.foreco.2013.07.004

Barilotti A, Turco S, Napolitano R, Bressan E (2005). La tecnologia LiDAR per lo studio della biomassa negli ecosistemi forestali [LiDAR technology for biomass study in forest ecosystems]. In: Proceedings of " $15^{\text {th }}$ Meeting of the Italian Society of Ecology". Turin (Italy) 12-14 Sept 2005, pp. 12-14. [In Italian]

Bartsch A, Widhalm B, Leibman M, Ermokhina K, Kumpula T, Skarin A, Wilcox EJ, Jones BM, Frost GV, Höfler A, Pointner G (2020). Feasibility of tundra vegetation height retrieval from Sentinel-1 and Sentinel-2 data. Remote Sensing of Environment 237: 111515. - doi: 10.1016/j.rse.20 19.111515
Bottalico F, Chirici G, Giannini R, Mele S, Mura M, Puxeddu M, McRoberts RE, Valbuena R, Travaglini $D$ (2017). Modeling Mediterranean forest structure using airborne laser scanning data. International Journal of Applied Earth Observation and Geoinformation 57: 145-153. - doi: 10.1016/j.jag.2016.12.013

Buchhorn M, Smets B, Bertels L, Lesiv M, Tsendbazar NE, Herold M, Fritz S (2019). Copernicus global land service: land cover 10om: epoch 2015: globe. Version V2.0.2. Presented at "ESA Living Planet Symposium 2019 (LPS2019)", Milan (Italy) 13-17 May 2019. Zenodo, web site. doi: $10.5281 /$ zenodo.3243509

Chiavetta U, Camarretta N, Garfì V, Ottaviano M, Chirici G, Vizzarri M, Marchetti M (2016). Harmonized forest categories in central Italy. Journal of Maps 12: 98-100. - doi: 10.1080/1744564 7.2016.1161437

Chirici G, McRoberts RE, Fattorini L, Mura M, Marchetti M (2016). Comparing echo-based and canopy height model-based metrics for enhancing estimation of forest aboveground biomass in a model-assisted framework. Remote Sensing of Environment 174: 1-9. - doi: 10.1016/j. rse.2015.11.010

Chirici G, Bottalico F, Giannetti F, Del Perugia B, Travaglini D, Nocentini S, Kutchartt E, Marchi E, Foderi C, Fioravanti $M$, Fattorini L, Bottai L, McRoberts RE, Corona P, Gozzini B (2018). Assessing forest windthrow damage using singledate, post-event airborne laser scanning data. Forestry 91: 27-37. - doi: 10.1093/forestry/cpxo 29

Chirici G, Giannetti F, McRoberts RE, Travaglini D, Pecchi M, Maselli F, Chiesi M, Corona P (2020). Wall-to-wall spatial prediction of growing stock volume based on Italian National Forest Inventory plots and remotely sensed data. International Journal of Applied Earth Observation and Geoinformatics 84, 101959. - doi: 10.1016/j.jag.20 19.101959

Corona P, Chianucci F, Quatrini V, Civitarese V, Clementel F, Costa C, Floris A, Menesatti P, Puletti $N$, Sperandio $G$, Verani $S$, Turco R, Bernardini V, Plutino M, Scrinzi G (2017). Precision forestry: concepts, tools and perspectives in Italy. Forest@ 14: 1-12. [In Italian with English summary] - doi: 10.3832/efor2285-014

Di Biase RM, Fattorini L, Marchi M (2018). Statistical inferential techniques for approaching forest mapping. A review of methods. Annals of Silvicultural Research 42: 46-58. - doi: 10.12899/ asr-1738

Dubayah R, Blair JB, Goetz S, Fatoyinbo L, Hansen $M$, Healey $S$, Hofton $M$, Hutt $G$, Kellner J, Luthcke S, Armstrong J, Tang H, Duncanson L, Hancock S, Jantz P, Marselis S, Patterson PL, Qi W, Silva C (2020). The global ecosystem dynamics investigation: high-resolution laser ranging of the Earth's forests and topography. Science of Remote Sensing 1: 100002. - doi: 10.1016/j. srs.2020.100002

Fattorini L, Marcheselli M, Pisani C (2006). A three-phase sampling strategy for large-scale multiresource forest inventories. Journal of Agricultural, Biological, and Environmental Statistics 11: 296-316. - doi: 10.1198/108571106X1305 48

Francini S, McRoberts RE, Giannetti F, Mencucci M, Marchetti M, Scarascia-Mugnozza G, Chirici
G (2020). Near-real time forest change detection using PlanetScope imagery. European Journal of Remote Sensing 53: 233-244. - doi: 10.1080/22797254.2020.1806734

Garnier M, Bastick C, Colin A, Commagnac L, Lallemant T, Maisonneuve B, Mazepa F, Simon M, Vega C (2019). La BD Forêt ${ }^{\oplus}$ version 2. L'IF - Synthèse périodique de l'inventaire forestier no. 46, Institut National de L'information Géographique et Forestière - IGN, Saint-Mandé, France. [in French] [online] URL: http://inven taire-forestier.ign.fr/IMG/pdf/lif_46_poster.pdf Giannetti F, Puletti N, Quatrini V, Travaglini D, Bottalico F, Corona P, Chirici G (2018). Integrating terrestrial and airborne laser scanning for the assessment of single-tree attributes in Mediterranean forest stands. European Journal of Remote Sensing 51: 795-807. - doi: 10.1080/ 22797254.2018.1482733

Giannetti F, Pegna R, Francini S, McRoberts RE, Travaglini D, Marchetti M, Scarascia-Mugnozza G, Chirici G (2020). A new method for automated clear-cut disturbance detection in Mediterranean coppice forests using Landsat time series. Remote Sensing 12 (22): 3720. - doi: 10.33 90/rs12223720

Goodwin NR, Coops NC, Culvenor DS (2006). Assessment of forest structure with airborne $\mathrm{Li}$ DAR and the effects of platform altitude. Remote Sensing of Environment 103: 140-152. doi: 10.1016/j.rse.2006.03.003

Hansen MC, Potapov PV, Moore R, Hancher M, Turubanova SA, Tyukavina A (2013). High-resolution global maps of $21^{\text {st }}$-century forest cover change. Science 342 (6160): 850-853. - doi: 10.1126/science. 1244693

Holopainen M, Vastaranta M, Hyyppä J (2014). Outlook for the next generation's precision forestry in Finland. Forests 5: 1682-1694. - doi: 10.3390/f5071682

Hüttich C, Korets M, Bartalev S, Zharko V, Schepaschenko D, Shvidenko A, Schmullius C (2014). Exploiting growing stock volume maps for large scale forest resource assessment: crosscomparisons of ASAR- and PALSAR-based GSV estimates with forest inventory in Central Siberia. Forests 5: 1753-1776. - doi: 10.3390/f5071753 Hyyppä J, Hyyppä H, Leckie D, Gougeon F, Yu X, Maltamo M (2008). Review of methods of small-footprint airborne laser scanning for extracting forest inventory data in boreal forests. International Journal of Remote Sensing 29 (5): 1339-1366. - doi: 10.1080/01431160701736489

INFC (2007). Le stime di superficie 2005 - Prima parte [Surface estimates - First part]. In: "Inventario Nazionale delle Foreste e dei Serbatoi Forestali di Carbonio" (Tabacchi G, De Natale F, Di Cosmo L, Floris A, Gagliano C, Gasparini P, Genchi L, Scrinzi G, Tosi V eds). MiPAF - Corpo Forestale dello Stato - Ispettorato Generale, CRA - ISAFA, Trento, Italy. [in Italian] [online] URL: http://www.infc.it

Isenburg M (2017). LAStools - efficient LiDAR processing software. Rapidlasso $\mathrm{GmbH}$, Gilching, Germany, web site. [online] URL: http:// rapidlasso.com/LAStools

Jakubowski MK, Guo Q, Kelly M (2013). Tradeoffs between LIDAR pulse density and forest measurements accuracy. Remote Sensing of Environment 103: 245-253. - doi: 10.1016/j.rse.2012. 11.024 
JAXA (2016). Global 25m resolution PALSAR-2 / PALSAR mosaic and forest / non-forest map (FNF) dataset description. Japan Aerospace Exploration Agency - JAXA, Earth Observation Research Center - EORC, Japan, pp. 8. [online] URL: https://www.eorc.jaxa.jp/ALOS/en/palsar fnf/DatasetDescription_PALSAR2_Mosaic_FNF _revE.pdf

Kangas A, Astrup R, Breidenbach J, Fridman J, Gobakken T, Korhonen KT, Maltamo M, Nilsson M, Nord-Larsen T, Olsson H (2018). Remote sensing and forest inventories in Nordic countries - Roadmap for the future. Scandinavian Journal of Forest Research 33: 397-412. - doi: 10.1080/02827581.2017.1416666

Langanke T (2017). Copernicus land monitoring service - high resolution layer forest. Product Specifications Document, Copernicus team, EEA, Copenhagen, Denmark, pp. 38. [online] URL: https://land.copernicus.eu/user-corner/tec hnical-library/hrl-forest

Maltamo $M$, Packalén P, Peuhkurinen J, Suvanto A, Pesonen A, Hyyppä J (2007). Experiences and possibilities of ALS based forest inventory in Finland. In: Proceedings of "ISPRS Workshop on Laser Scanning 2007 and SilviLaser 2007" Espoo (Finland) 12-14 Sept 2007, pp. 270-279.

Maltamo M, Naesset E, Vauhkonen J (2014). Forestry applications of airborne laser scanning: concepts and case studies. Springer, Dordrecht, Netherlands, pp. 464. - doi: 10.1007/978 94-017-8663-8

Maltamo M, Orka HO, Bollandsås OM, Gobakken $\mathrm{T}$, Naesset $\mathrm{E}$ (2015). Using pre-classification to improve the accuracy of species-specific forest attribute estimates from airborne laser scanner data and aerial images. Scandinavian Journal of Forest Research 30: 336-345. - doi: 10.1080/028 27581.2014.986520

McRoberts RE, Bechtold WA, Patterson PL, Scott CT, Reams GA (2005). The enhanced Forest Inventory and Analysis program of the USDA Forest Service: historical perspective and announcement of statistical documentation. Journal of Forestry 103: 304-308. - doi: 10.1093/ jof/103.6.304

McRoberts RE, Naesset E, Gobakken T (2013). Inference for LiDAR-assisted estimation of forest growing stock volume. Remote Sensing of Environment 128: 268-275. - doi: 10.1016/j.rse.2012. 10.007

McRoberts RE, Liknes GC, Domke GM (2014). Using a remote sensing-based, percent tree cover map to enhance forest inventory estimation. Forest Ecology and Management 331: 12-18. doi: 10.1016/j.foreco.2014.07.025
Montaghi A, Corona P, Dalponte M, Gianelle D, Chirici G, Olsson H (2013). Airborne laser scanning of forest resources: an overview of research in Italy as a commentary case study. International Journal of Applied Earth Observation and Geoinformation 23: 288-300. - doi: 10.1016/j.jag.2012.10.002

Mura M, McRoberts RE, Chirici G, Marchetti M (2016). Statistical inference for forest structural diversity indices using airborne laser scanning data and the k-nearest neighbors technique. Remote Sensing of Environment 186: 678-686. doi: 10.1016/j.rse.2016.09.010

Naesset E (2002). Predicting forest stand characteristics with airborne scanning laser using a practical two-stage procedure and field data. Remote Sensing of Environment 80: 88-99. doi: 10.1016/So034-4257(01)00290-5

Naesset E (2007). Airborne laser scanning as a method in operational forest inventory: status of accuracy assessments accomplished in Scandinavia. Scandinavian Journal of Forest Research 22: 433-422. - doi: 10.1080/028275807016 72147

Naesset E, Gobakken T, Solberg S, Gregoire TG, Nelson R, Ståhl G, Weydahl D (2011). Model-assisted regional forest biomass estimation using LiDAR and InSAR as auxiliary data: a case study from a boreal forest area. Remote Sensing of Environment 115: 3599-3614. - doi: 10.1016/j.rse. 2011.08.021

Nilsson M, Nordkvist K, Jonzén J, Lindgren N, Axensten P, Wallerman J, Egberth M, Larsson S, Nilsson L, Eriksson J, Olsson H (2017). A nationwide forest attribute map of Sweden predicted using airborne laser scanning data and field data from the National Forest Inventory. Remote Sensing of Environment 194: 447-454. doi: 10.1016/j.rse.2016.10.022

Puletti N, Floris A, Scrinzi G, Chianucci F, Colle G, Michelini T, Pedot N, Penasa A, Scalercio S, Corona P (2017). CFOR: a spatial decision support system dedicated to forest management in Calabria. Forest@ 14: 135-140. [In Italian with English summary] - doi: 10.3832/efor2363-014

Saarela S, Holm S, Grafström A, Schnell S, Gregoire TG, Nelson RF, Ståhl G (2016). Hierarchical model-based inference for forest inventory utilizing three sources of information. Annals of Forest Science 73: 895-910. - doi: 10.1007/s1359 5-016-0590-1

Scrinzi G, Floris A, Clementel F, Bernardini V, Chianucci F, Greco S, Michelini T, Penasa A, Puletti N, Rizzo M, Turco R, Corona P (2017). Models of stand volume and biomass estimation based on LiDAR data for the main forest types in Calabria (southern Italy). Forest@ 14: 175-187. [In Italian with English summary] - doi: 10.3832/efor2399014

Smith S, Gilbert J, Bull G, Gillam S, Whitton E (2010). National inventory of woodland and trees (1995-99): methodology. Forestry Commission Research Report, Forestry Commission Scotland, Edinburgh, UK, vol. i-iv, pp. 1-60. Tompalski P, White JC, Coops NC, Wulder MA (2019). Demonstrating the transferability of forest inventory attribute models derived using airborne laser scanning data. Remote Sensing of Environment 227: 110-124. - doi: 10.1016/j.rse. 2019.04.006

Valbuena R, Packalen P, Mehtätalo L, GarcíaAbril A, Maltamo M (2013). Characterizing forest structural types and shelterwood dynamics from Lorenz-based indicators predicted by airborne laser scanning. Canadian Journal of Forest Research 43: 1063-1074. - doi: 10.1139/cjfr-20 13-0147

Vihervaara P, Mononen L, Auvinen AP, Virkkala R, Lü Y, Pippuri I, Packalen P, Valbuena R, Valkama J (2015). How to integrate remotely sensed data and biodiversity for ecosystem assessments at landscape scale. Landscape Ecology 30: 501-516. - doi: 10.1007/s10980-014-0137-5 Vizzarri M, Sallustio L, Travaglini D, Bottalico F, Chirici G, Garfì V, Lafortezza R, Veca DSLM, Lombardi F, Maetzke F, Marchetti M (2017). The MIMOSE approach to support sustainable forest management planning at regional scale in Mediterranean contexts. Sustainability 9 (2): 316. - doi: 10.3390/su9020316

Vogeler JC, Hudak AT, Vierling LA, Evans J, Green $P$, Vierling KT (2014). Terrain and vegetation structural influences on local avian species richness in two mixed-conifer forests. Remote Sensing of Environment 147: 13-22. - doi: 10.1016/j.rse.2014.02.006

Waser LT, Ginzler C, Rehush N (2017). Wall-towall tree type mapping from countrywide airborne remote sensing surveys. Remote Sensing 9 (8): 766 . - doi: 10.3390/rs9080766

White JC, Coops NC, Wulder MA, Vastaranta M, Hilker T, Tompalski P (2016). Remote sensing technologies for enhancing forest inventories: a review. Canadian Journal of Remote Sensing 42: 619-641. - doi: 10.1080/07038992.2016.12074 84

Wulder MA, Bater CW, Coops NC, Hilker T, White JC (2008). The role of LiDAR in sustainable forest management. Forest Chronicle 84: 807-826. - doi: $10.5558 /$ tfc $84807-6$ 